UDC 615.012:004.738.5

https://doi.org/10.24959/uekj.17.30

I. V. Timanyuk, I. V. Pestun

National University of Pharmacy

\title{
STRUCTURAL ANALYSIS OF PROFESSIONAL PHARMACEUTICAL INTERNET-RESOURCES
}

The current information field, taking into account the number of streams of information and its sources, necessitates the evaluation and combination of available resources of the pharmaceutical market with the content, the level of reliability, relevance and timeliness of information provision, its completeness, sufficiency, etc.

Aim. To systematize and categorize Internet information sources in Ukraine as an applied marketing tool to increase the efficiency of the activities and improve the quality of pharmaceutical care to the population.

Results. In the article analyzed and categorized information flows available to specialists for more effective use of information and the formation of a system of loyalty to various sources. Analyzed the main Internet resources of marketing pharmaceutical information that are accessible and popular among pharmacists, proposed their classification. Analyzed the statistics of visits to the main Internet resources of the pharmaceutical field.

Conclusions. Divided the main Internet resources into 5 categories, analyzed the content of each of them. Proposed the cycle of analysis of professional information on the Internet and highlighted the main directions of further research.

Key words: sources of information, Internet resources, marketing researches, databases

\section{I. В. ТІманюК, I. В. ПЕСтУН}

\section{СТРУКТУРНИЙ АНАЛІЗ ПРОФЕСІЙНИХ ФАРМАЦЕВТИЧНИХ ІНТЕРНЕТ-РЕСУРСІВ}

Сучасне інформаційне поле, враховуючи кількість потоків інформації та їі джерел, зумовлює необхідність оцінювання і поєднання фахівцями фармацевтичного ринку наявних ресурсів за змістовим наповненням, рівнем достовірності, актуальності та своєчасності надання інформації, ії повноти, достатності тощо.

Метою роботи є систематизація і категоризація інформаційних Інтернет-джерел в Україні як прикладного маркетингового інструменту для збільшення ефективності діяльності і підвищення якісної складової фармацевтичної допомоги населенню.

Результати. У статті проведено аналіз і категоризацію інформаційних потоків, доступних фахівцям для більш ефективного використання інформації і формування системи лояльності до різних джерел. Проаналізовані основні інтернет-ресурси маркетингової фармацевтичної інформації, які є доступними і популярними серед спеціалістів фармації, запропоновано їх класифікацію. Проаналізована статистика відвідувань основних інтернет-ресурсів фармацевтичного спрямування.

Висновки. Основні інтернет-ресурси розподілені на 5 категорій, проаналізований зміст контенту кожної з них. Запропоновано цикл аналізу професійної інформації в Інтернеті та виділені основні напрямки подальших досліджень.

Ключові слова: джерела інформації; інтернет-ресурси; маркетингові дослідження; бази даних

И. В. ТИМАНЮК, И. В. ПЕСТУН

СТРУКТУРНЫЙ АНАЛИЗ ПРОФЕССИОНАЛЬНЫХ ФАРМАЦЕВТИЧЕСКИХ ИНТЕРНЕТРЕСУРСОВ

Современное информационное поле, учитывая количество потоков информации и ее источников, обусловливает необходимость оценки и распределения специалистами фармацевтического рынка имеющихся ресурсов по смысловому наполнению, уровню достоверности, актуальности и своевременности предоставления информации, ее полноте, достаточности и т. д.

Целью работы является систематизация и категоризация информационных интернетисточников в Украине как прикладного маркетингового инструмента для увеличения эффективности деятельности и повышения качественной составляющей фармацевтической помощи населению. 
Результаты. В статье проведен анализ и категоризация информационных потоков, доступных специалистам для более эффективного использования информации и формирования системы лояльности к различным источникам. Проанализированы основные интернетресурсы маркетинговой фармацевтической информации, которые доступны и популярны среди специалистов фармации, предложена их классификация. Проанализирована статистика посещений основных интернет-ресурсов фармацевтического направления.

Выводы. Основные интернет-ресурсы распределены на 5 категорий, проанализировано содержание контента каждой из них. Предложен цикл анализа профессиональной информации в Интернете и выделены основные направления дальнейших исследований.

Ключевые слова: источники информации; интернет-ресурсы; маркетинговые исследования; базы данных

\section{STATEMENT OF THE PROBLEM}

One of the peculiarities of the modern pharmaceutical market in Ukraine is a large and at the same time limited amount of information. On the one hand, we have access to any resource, and on the other hand, there is no set of indicators, especially statistics, regarding the health system, the pharmaceutical market, independent information on the use of medicines, data of the activities of participants in the pharmaceutical market (production, wholesale and pharmacy organizations) and other. At the same time, the factor of successful development of each organization is the use of information and communication technologies, both for interaction with clients and suppliers, as well as the basis of internal management processes. Such a situation has led to the emergence of a number of issues that are necessary to resolve, it is the search for relevant information, its accumulation, sorting, categorization according to certain criteria, storage in conditions of optimization of resources, the formation of a system for rapid processing of requests, etc.

The market for information products and information services is constantly expanding and changing, that is why pharmaceutical companies faced with the problem of choosing the best information resources that can satisfy most of the information needs.

In view of this situation, it is necessary a study on existing information sources and professional opportunities for their use in pharmaceutical organizations.

The basis of the research methodology is the systematic approach to the analysis of the structural characteristics of the information flows of the Ukrainian pharmaceutical market.

The objects of the study were professional information resources used in marketing activities of pharmaceutical companies.

In the process of research used the following methods: system approach, comparative, structural-logical analysis, analytical grouping of data.

\section{ANALYSIS OF RECENT RESEARCHES AND PUBLICATIONS}

In foreign literature today dealt with the beginning of the formation of a majority government programs to create a common information space in the health and social development. In the framework of implementation of these projects, monitoring of the level of automation of health care organizations carried out, indicators are determined: equipment of the PC, availability of access to the Internet, level of skills of using the PC of medical and pharmaceutical workers, etc. [1].

Analysis of literary sources showed that at various times the researchers considered issues in the field of pharmaceutical information (A.S. Nemchenko, G. V. Shashkova, O. V. Posilkina), informatization of medical care to the population and development of information systems (Z. M. Mnushko, V. M. Tolochko, Yu. P. Medvedeva, L. V. Moshkova), informational activity and information environment of the pharmacy (I. V. Olkhova, I. G. Grinchuk, M. P. Tymoshchuk), marketing and advertising information (N. B. Dremova, O. M. Yevtushenko), informational support of OTC leave (B. P. Gromovik, A. A. Kotvitska, A. V. Soloninina), Peculiarities - of marketing research in pharmacy (I. V. Pestun).

\section{IDENTIFICATION OF ASPECTS OF THE PROBLEM UNSOLVED PREVIOUSLY}

Over the last decade, the information sphere has changed globally, transformed its capabilities, boundaries and technologies. However, systematic approaches to assessing its potential and its use in the management process require constant improvement taking into account time requirements. Works on improvement the effective information of pharmaceutical companies activities, its scope and value optimization are not sufficiently represented. At the same time the continuous development of information and communication technologies on the background of rapid aging of existing developments.

\section{OBJECTIVE STATEMENT OF THE ARTICLE}

The purpose of this study is to systematize and categorize Internet information sources in Ukraine as an applied marketing tool to increase the efficiency of activities and improve the quality of pharmaceutical assistance to the population.

\section{PRESENTATION OF THE MAIN}

MATERIAL FOR THE RESEARCH

Among the available today's automated informational products that are used in pharmacy it can be 


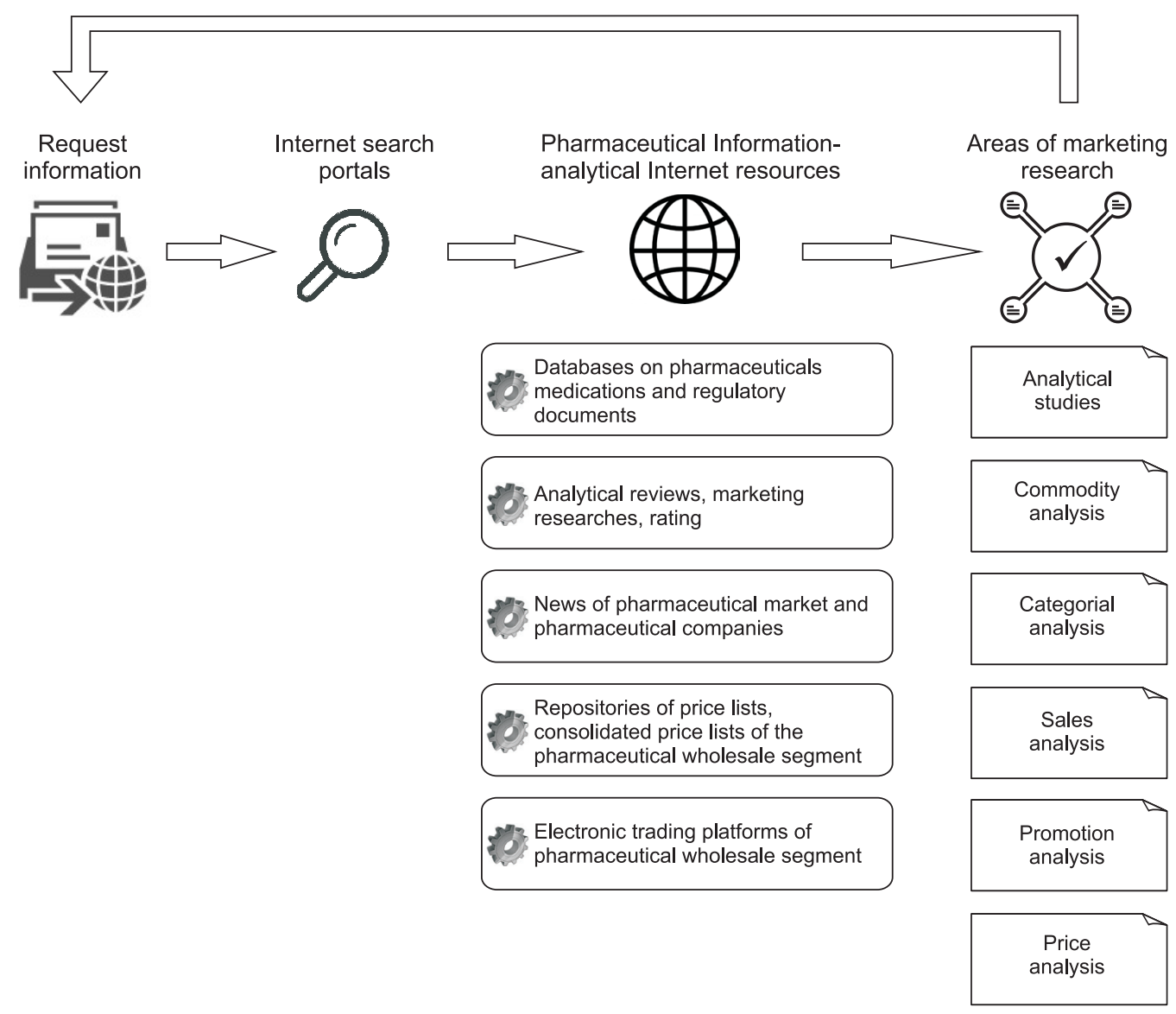

Fig. 1. The cycle of analysis of information on the Internet

distinguish at 6 types: electronic sources of pharmaceutical information; databases; automated information systems (expert systems, automated databases, knowledge bases); Internet sites; hardware and software complexes (automated workplace, automated enterprise management system); other software as a applications or application packages for solving various practical tasks [2].

The rapid increase in the number of users and the need for information stimulates the development of the pharmaceutical Internet space [3-5]. Internet sites contain websites of pharmaceutical manufacturers, distributors, pharmacies, as well as websites of government agencies and large information portals. They differ in goals and objectives and, accordingly, in the target audience and information $[6,7]$.

In spite of the positive features of using the Internet as a source of medical and pharmaceutical information, a significant disadvantage is the lack of effective standards for the quality and reliability of information provided on sites [8]. According to recent research (May 2017) in Ukraine undisputed leader in search remains Google (75.7 \%), second place is Yandex (18.33\%), other search engines amounting to occupy only $6 \%$ of the market [9]. Analysis cycle of information consists of a direct request up to a final marketing research and the information and analytical sites are the main links studied by the researcher after the general request, and find relevant information with built-in internal search engines (Fig. 1) [10].

All sources of information used by specialists in pharmaceutical market we divided into categories based on of professional Internet resources for the information provided in them (databases, a large amount of scientific, market, analytical, marketing information, etc.). Thus, 5 categories were formed: A - databases on regulatory documentation and medicines; $\mathrm{B}$ - sites with marketing research, analytical reviews, ratings; $\mathrm{C}$ - news of the pharmaceutical sector; D - price lists, consolidated price lists of the wholesale segment of the pharmaceutical market; E - electronic trading platforms of a wholesale segment of the pharmaceutical market.

Typically, specialized pharmaceutical or medical sites are narrow-minded, but most modern Ukrainian sites seek to provide their client with all the necessary information by engaging partners in their information portal.

In the study we have identified practical value of information-analytical sites and given their membership of a particular category, and analyzed the popularity of resources by the number of visits, presented the trend line (Table). 


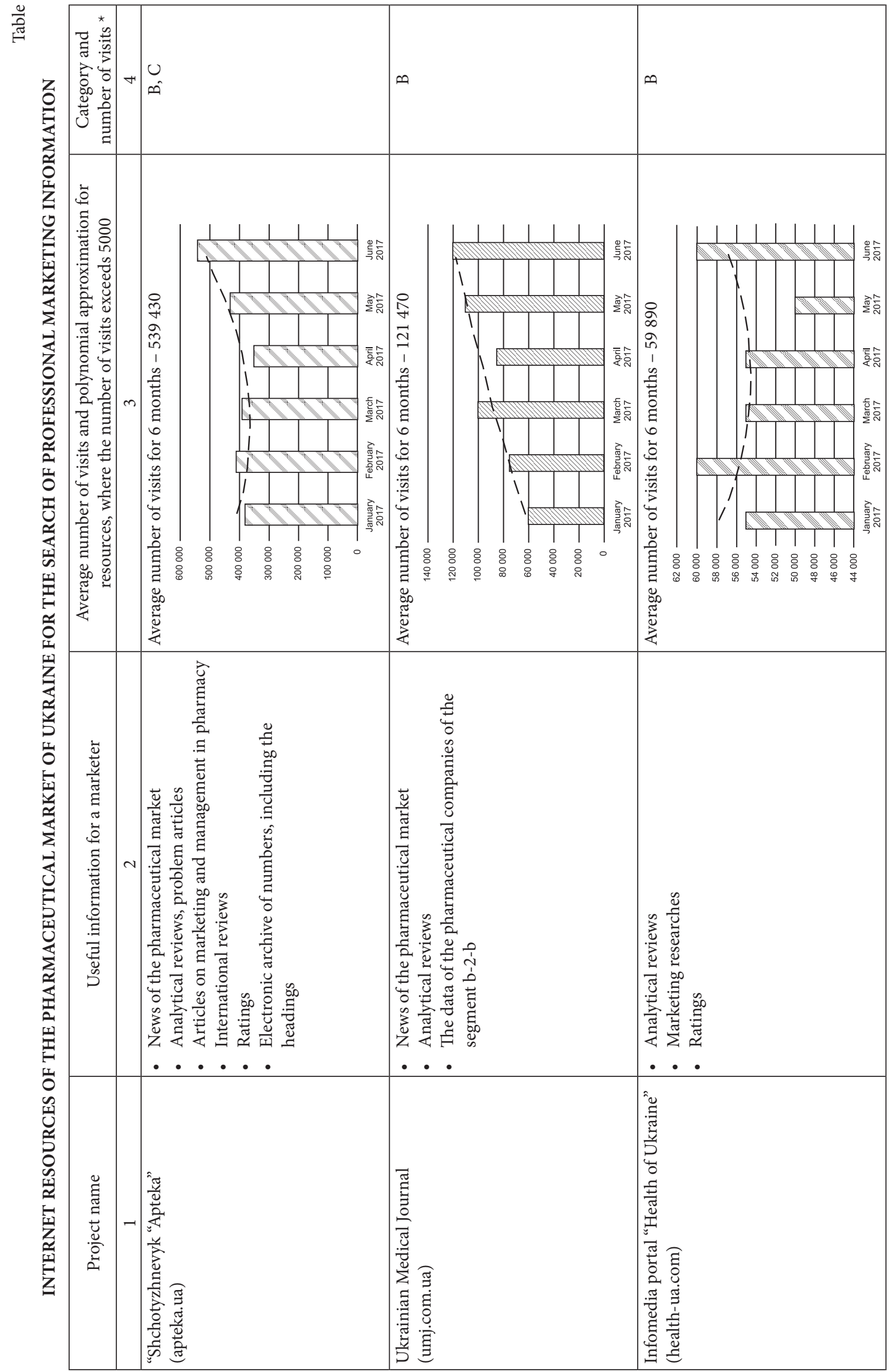




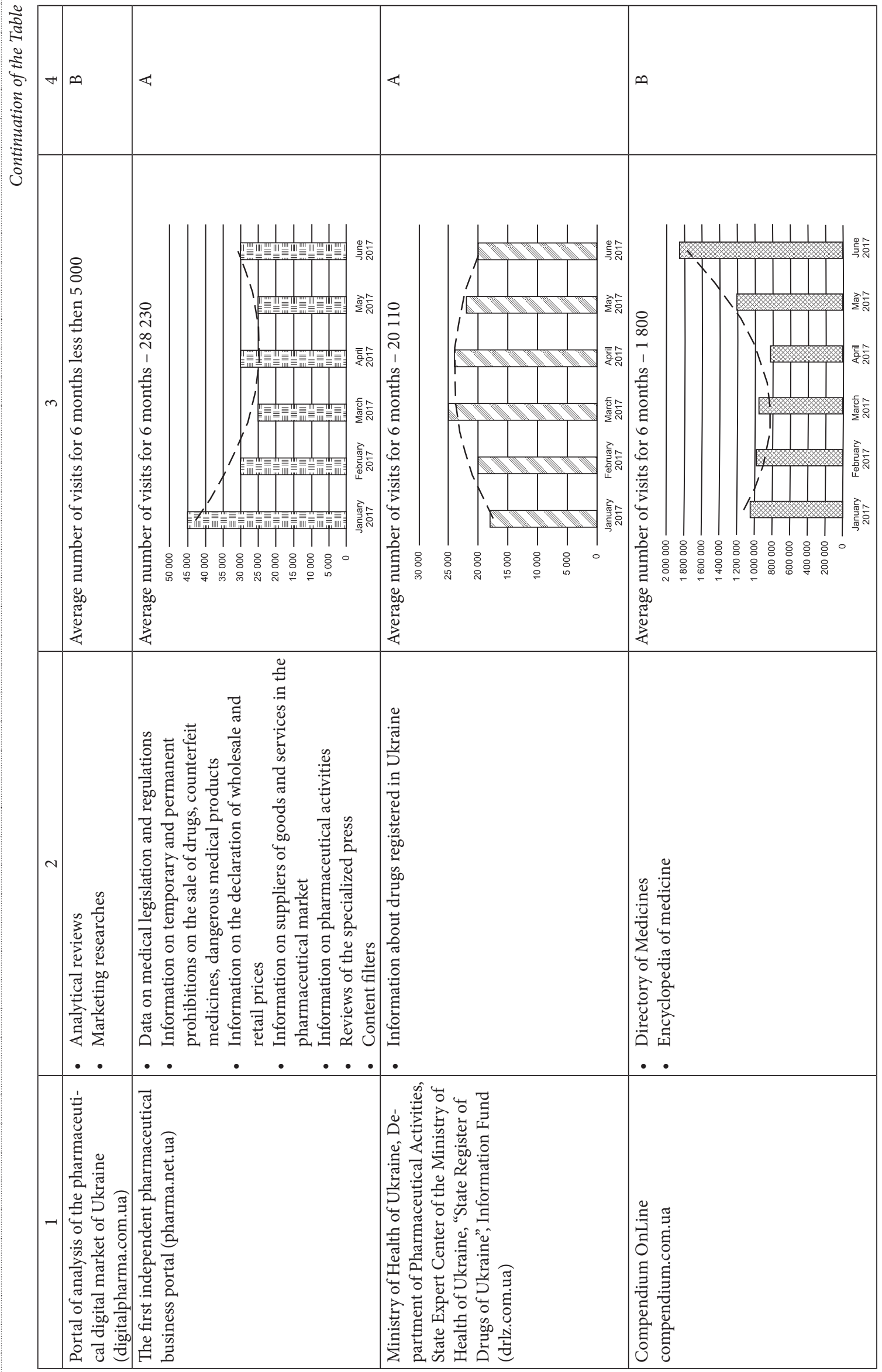

$[56]$ 


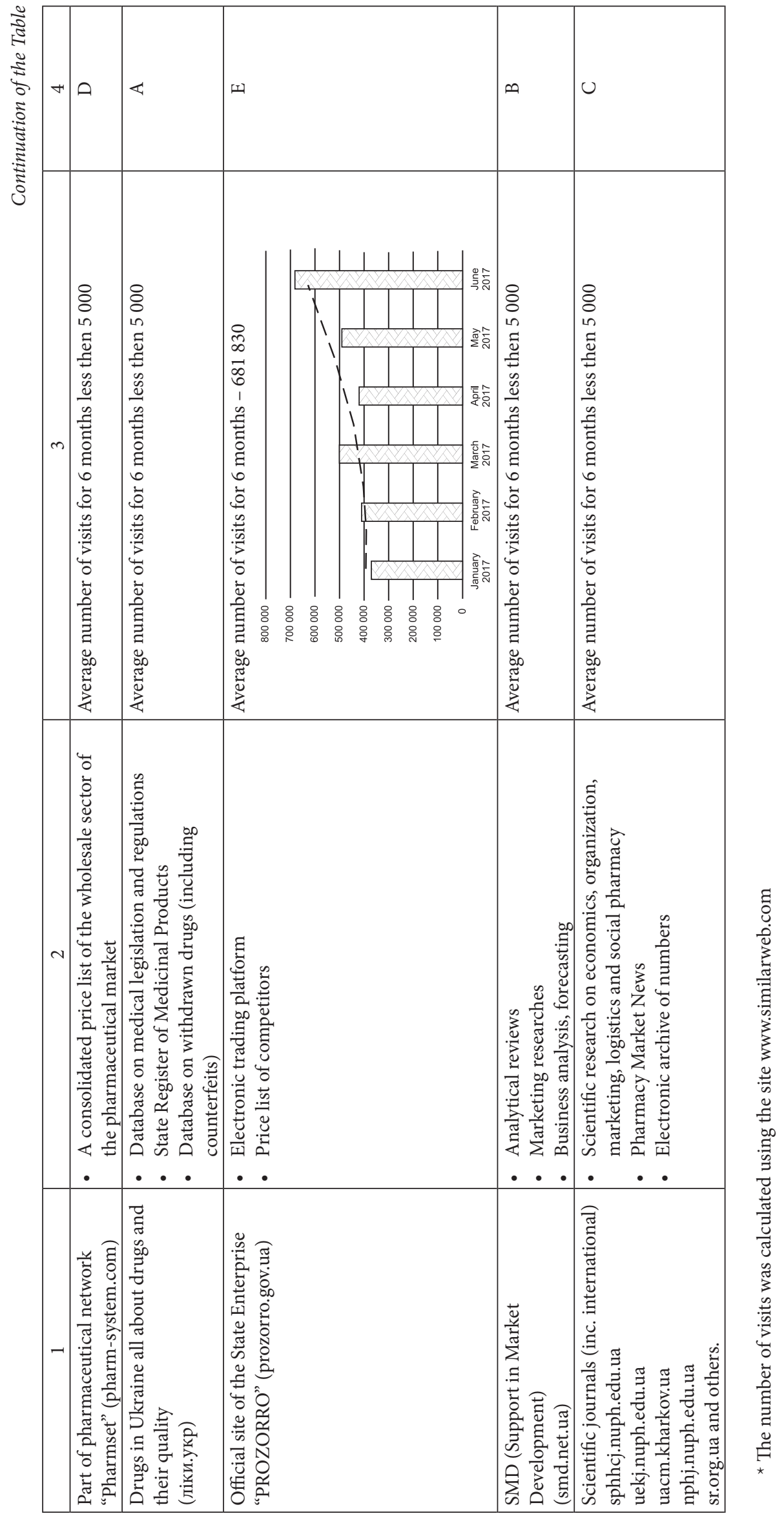


Category A (databases on regulatory documentation and medicines) includes information sources that pay more attention to regulatory documents:

- The first independent pharmaceutical business portal pharma.net.ua. A convenient site for finding information on legislation and regulations, a database of withdrawn drugs (including counterfeits), information on wholesale and retail prices, general information about suppliers of pharmaceutical products and services, press reviews, etc. As well as relevant information about the activities of the pharmaceutical profile are exhibitions, seminars, conferences, congresses, etc. The site has content filters that are capable of filtering the necessary information in all sections (news, articles, events, etc.) only the profile materials remain visible.

- Information retrieval system of the "State Register of Drugs of Ukraine" drlz.com.ua, which was formed by the State Enterprise "State Expert Center of the Ministry of Health of Ukraine". The system provides information on registered medicinal products and instructions for medical use in Ukraine.

- Information portal created by the public association "All-Ukrainian Association for the Protection of the Rights of Consumers of Medicinal Products and Medical Products" - medicine.ukr. Provides business entities licensed for the production of medicinal products, wholesale and retail trade in pharmaceuticals, comprehensive information on medicines, medical products, special food products, documents and information on their circulation and quality control.

In addition to normative databases, there is a constant need for information on current trends in the pharmaceutical market, which uses analytical reviews, marketing research, and ratings.

Category B (sites with marketing research, analytical reviews, ratings) contains:

- Infomedia portal "Health of Ukraine" health-ua.com. The Internet portal contains relevant information; reviews of thematic conferences, symposiums, congresses, congresses; covered the actual aspects of practically all spheres of medicine and pharmacy. This portal is sought-after platform for 15 years to exchange ideas and links between science and practice.

- Ukrainian Medical Journal - umj.com.ua. The site contains relevant information, which is gathered in 21 sections among which is the heading "management and marketing in the health system". The site also provides users with information on medical and pharmaceutical organizations operating both in Ukraine and abroad. Digitalpharma.com.ua - Digital Pharma team provides analytical reports of the situation on the pharmaceutical market of Ukraine as a whole and for the main categories of drugs.

- Professional information portal Support in Market Development - smd.net.ua. Key areas of acti- vity of this organization are marketing researches of pharmaceutical markets of Ukraine, Azerbaijan, Armenia, Georgia, Belarus, Kazakhstan, Kyrgyzstan, Moldova, Russia, Tajikistan and Uzbekistan.

- Compendium - compendium.com.ua - a popular online directory of medicines. It is possible to find not only information about the composition and effect of drugs, but also prices for drugs, manufacturers, $\mathrm{MOH}$ instructions, classification of dietary supplements for food and cosmetics, etc.

Category C (news pharmaceutical sector) also contains information about the pharmaceutical market, which is more scientific in nature:

- Official site of the newspaper "Shchotyzhnevyk "Apteka" - apteka.ua. This is one of the most popular media on the pharmaceutical market. In addition to regularly updated news and bases of normative documents, the site has free access to the archive of all previous issues of the newspaper and current prices for medicines and medical products.

- Scientific journals (sphhcj.nuph.edu.ua, uekj.nuph.edu.ua, uacm.kharkov.ua, nphj.nuph.edu.ua, sr.org.ua, etc.). The sites present modern scientific research, which carried out in various educational institutions of the country, as well as analytical and comparative articles.

One of the types of work of specialists in pharmaceutical companies is the price list analysis. For this purpose, can be used online resources that were in category $\mathbf{D}$ (price lists, consolidated price lists of the wholesale segment of the pharmaceutical market).

This category also includes the informational site pharm-system.com, which is in the promotion stage, so the list of prices is limited at this time. The site proposed to establish a special soft shell that will receive daily updates subscription wider range of price lists over the Internet.

The last category is the category $\mathbf{E}$, which contains electronic trading platforms of the wholesale segment of the pharmaceutical market. Currently, the most popular electronic trading platform is prozorro.gov.ua. Pharmaceutical companies are beginning to take part in public procurement, it is convenient and affordable, since all relevant procurement, information is on-line and in addition, it is possible to set up a receipt for news on current tenders.

Our analysis of visits statistics showed that the first place among the professional pharmaceutical Internet sources is "Shchotyzhnevyk "Apteka", on average, in the 1 month it visited by about 90 thousand visitors. But such an indicator, as well as the rest of the data, can indicate that some resources are attracting not only professional users but also ordinary consumers to their pages. By contrast, only a limited number of professionals visit the resources of scientific journals (Figure 2).

Conducted analysis allows objectively assess the content of the main Internet resources used by 


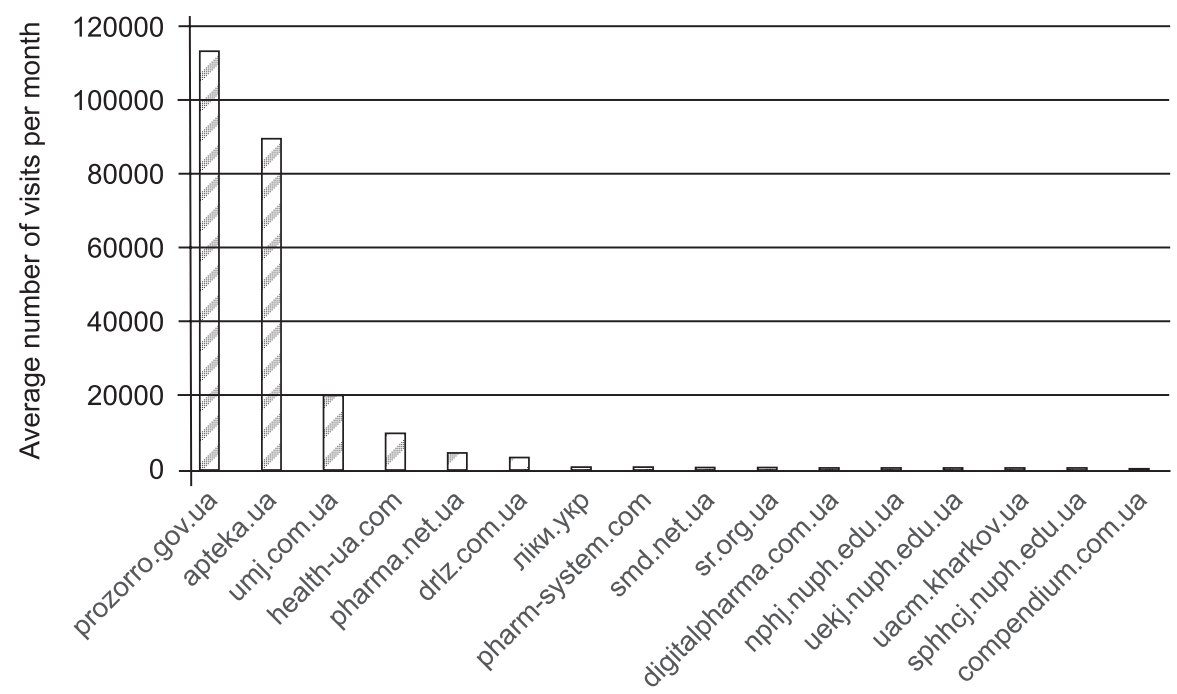

Fig. 2. Statistics of monthly visits on investigated Internet resources

specialists in the pharmaceutical market. Demand and attention from the experts demonstrates the analysis of visits to individual resources. It is necessary depth analysis of the information needs of the pharmaceutical and needed the directing of information flows to cover the most pressing issues. At the same time, an analysis of the existing information space in Ukraine and abroad may be conducted in order to identify new opportunities for providing and obtaining information.

\section{CONCLUSIONS AND PROSPECTS FOR FURTHER RESEARCH}

1. The categorization of the most common professional internet resources used by pharmaceutical market specialists in the sphere of marketing activity was conducted. Available Internet resources are divided into 5 categories by content.

2. Provided a characteristic of content of Internet resources and analyzed the visits of each of them.

In further research, it planned to conduct a comparative analysis of existing Internet resources in Ukraine with similar ones used by pharmacists in Europe to develop a methodical approach to creating a unified Internet resource for pharmacists.

Conflict of Interests: authors have no conflict of interests to declare.

ABBREVIATIONS

OTC, over the counter; $\mathrm{MOH}$, Ministry of Health

\section{REFERENCES}

1. Копаница, Г. Д. Европейский опыт и пути развития информатизации системы здравоохранения / Г. Д. Копаница, Ж. Ю. Цветкова // Врач и информационные технол. - 2013. - № 1. - С. 49-53.

2. Timanyuk, I. The analysis of digital tiered pharmacy formation / I. Timanyuk, I. Pestun // ScienceRise : Pharmaceutical Science. - 2017. - Vol. 0, Issue 3 (7). - P. 41-50. doi: 10.15587/2519-4852.2017.104237

3. Каткова, А. Д. Интернет-технологии при организации фармацевтической помощи населению / А. Д. Каткова, И. А. Кирщина, А. В. Солонинина // Новая аптека. - 2013. - № 5. - С. 19-21.

4. Promoting Participatory Medicine with Social Media : New Media Applications on Hospital Websites that Enhance Health Education and ePatients' Voices / L. M. Gallant, C. Irizarry, G. Boone, G. L. Kreps // J. of Participatory Medicine. - 2011. - Vol. 3 - Available at : http://www.jopm.org/evidence/research/2011/10/31/ promoting-participatory-medicinewith-social-media-new-media-applications-on-hospital-websites-that-enhance-healtheducation-and-e-patients-voices/

5. McMullan, M. Patients Using the Internet to Obtain Health Information : How This Affects the PatientHealth Professional Relations / M. McMullan // Patient Education and Counseling. - 2006. - Vol. 63, Issue 1-2. - Р. 24-28. doi: 10.1016/j.pec.2005.10.006

6. Гасилин, Д. Интернет-сайт для несетевой аптеки / Д. Гасилин // Фармацевтическое обозрение. 2013. - № 12 (141). - C. 40-41.

7. Macias, W. How well do direct to consumer, DTC, prescription drug web sites meet FDA guidelines and public policy concerns? / W. Macias, L. Lewis Stavchansky // Health Mark Quarterly. - 2005. - Vol. 22, Issue 4. - P. 45-71. doi: 10.1300/j026v22n04_04

8. Толочко, В. М. К вопросу контроля за фармацевтической информацией, предоставляемой через сеть Интернет / В. М. Толочко, Ю. П. Медведева, О. Н. Должникова // Международная конференция 
«Медико-социальная экология личности: состояние и перспективы»: материалы IX междунар. конф., 1-2 апреля 2011 г., Минск. - Минск, 2011. - С. 405-406.

9. Юдин, А. Рейтинг поисковых систем в 2017 (статистика стран СНГ и мира) [Электронный ресурс] / А. Юдин // Marketer. - 2017. - Режим доступа : https://marketer.ua/rejting-poiskovyh-sistemv-2017-statistika-stran-sng-i-mira/

10. Нилов, В. Н. Интернет и маркетинговые исследования в оптовом сегменте фармацевтического рынка. Обзор фармацевтических интернет-ресурсов глазами маркетолога / В. Н. Нилов // Индустриальный и b2b маркетинг. - 2008. - № 3. - С. 244-252.

\section{REFERENCES}

1. Kopanitca, G. D., Tcvetkova, Zh. Yu. (2013). Vrach i informatcionnye tekhnologii, 1, 49-53.

2. Timanyuk, I., Pestun, I. (2017). The analysis of digital tiered pharmacy formation. ScienceRise: Pharmaceutical Science, 0 (3 (7)), 41-50. doi: 10.15587/2519-4852.2017.104237

3. Katkova, A. D.,Kirshchina, I. A., Soloninina, A. V. (2013). Novaia apteka, 5, 19-21.

4. Gallant, L. M., Irizarry, C., Boone, G., Kreps, G. L. (2011). Promoting Participatory Medicine with Social Media: New Media Applications on Hospital Websites that Enhance Health Education and ePatients' Voices. Journal of Participatory Medicine, 3. Available at: http://www.jopm.org/evidence/research/2011/10/31/ promoting-participatory-medicinewith-social-media-new-media-applications-on-hospital-websites-that-enhance-healtheducation-and-e-patients-voices/

5. McMullan, M. (2006). Patients using the Internet to obtain health information : How this affects the patient-health professional relationship. Patient Education and Counseling, 63 (1-2), 24-28. doi: 10.1016/j. pec.2005.10.006

6. Gasilin, D. (2013). Farmatcevticheskoe obozrenie, 12 (141), 40-41.

7. Macias, W., Lewis, L. S. (2006). How Well Do Direct-to-Consumer (DTC) Prescription Drug Web Sites Meet FDA Guidelines and Public Policy Concerns? Health Marketing Quarterly, 22 (4), 45-71. doi: 10.1300/j026v22n04_04

8. Tolochko, V. M., Medvedeva, Yu. P., Dolzhnikova, O. N. (2011). K voprosu kontrolia za farmatcevticheskoi informatciei, predostavlennoi cherez set Internet. Minsk, 405-406.

9. Yudin, A. (2017). Marketer. Available at: https://marketer.ua/rejting-poiskovyh-sistem-v-2017-statistikastran-sng-i-mira/

10. Nilov, V. N. (2008). Industrialnyi i b2b marketing, 3, 244-252.

Адреса для листування:

61168, м. Харків, вул. Валентинівська, 4.

E-mail: timanjuk@gmail.com.

Національний фармацевтичний університет

Тіманюк I. B. (ORCID - http://orcid.org/0000-0003-3569-0323)

Пестун I. B. (ORCID - http://orcid.org/0000-0002-4114-3564) 